\title{
Garnet response diamond pressure metamorphism from Tso-M orari region, Ladakh, India
}

\author{
Barun K Mukherjee* and Himanshu K Sachan \\ Wadia Institute of Himalayan Geology, DehraDun-248 001, INDIA \\ * To whom correspondence should be addressed. E-mail: mukherjebarun@yahoo.co.in
}

Garnet is most promising container for the metamorphic event. Thesignificance of garnetsfrom metamorphic rocksas container of primary mineral inclusion and its uniqueness due to act as pressurevessels is noticed in coesite-eclogiteby giving Diamond pressure or facies metamorphism (UHP) in the Tso-Morari Region. The Tso-Morari dome in eastern Ladakh stretches 500 $\mathrm{Km}^{2} \mathrm{NW}$ to SE. The dome is surrounded by Indus suture zone rocks to the north by Zildat detachment fault and south by lowgrade sedimentary rocks. Structurally, the lowest rocks exposed in thecomplexarePugaGneisses within that boudinaged eclogite have unidirectional pattern, which is parallel to the foliation of host gneisses.

The Tso-Morari eclogites hosted by peletic and paragneisses, occur as two types- massive, dark-coloured type and crystalline light-coloured type. The fresh crystalline type eclogites are coarser ( $>500$ micron in size), having biminerallic component of garnet and clinopyroxene. The hexagonal to octahedral garnet porphyry contains inclusions of carbonates including magnesite, calcite/ aragonite, dolomite, phengite, paragonite, kyanite, magnesiostaurolite, rutileand silica phases like quartz, coesite etc.

The garnet consisting essentially of almandine-pyropegrossular solid solution were in the alm-67-42\%, pyr-8-35\%, gros $-4-25 \%$, whereas spessitine component always being less than $5 \%$, and usually less than $1 \%$. The reversible pattern of $\mathrm{Mg} /$ $\mathrm{Mn}$ exhibits increase of $\mathrm{Mgand}$ decrease of $\mathrm{Mn}$ and $\mathrm{Ca}$, from core to rim supportstrong progradezonation, except the outer rim of garnet showing retrograde pattern due to exchange of $\mathrm{Fe} / \mathrm{Mg}$ during cooling and exhumation. Furthermorethemantleportion is rich in pyrope and grossular, which marked and favoured the maximum pressure zone within the garnet porhyroblast.

The inclusions phase assemblages markedly noticed by quartzcoesite, magnesite-quartz-talc, kyanite-paragonite-jadeite component in pyroxene, magnesiostaurolite-pyrope-kyanite, talc-staurolite-kyanite-pyrope, coesite -dolomite-diopside, coesite-magnesite-enstatite etc. within the garnet as in hetrogenity.

A peak and prograde P-T estimation by sequential geothermobarometry of UHP metamorphic rocks ofTMC region documented by the presence of $\mathrm{Mg}-\mathrm{Qz}-\mathrm{Tl} \mathrm{c}$ is stablein therange of $\mathrm{T} \sim 400-600{ }^{\circ} \mathrm{C}$ and $\mathrm{P} \sim 4-28 \mathrm{kbar}, \mathrm{Pg}-\mathrm{Ky}-\mathrm{Jd}$ is stable at 440-650 ${ }^{\circ} \mathrm{C}$ and $\mathrm{P} \sim 13-22 \mathrm{kbar}$ whereasTlc-St-Ky-Py in which, the $\mathrm{Mg}$-rich staurolite(Fe/ Mg in tetrahedral coordination) could be high pressure phasein $\mathrm{T}>700^{\circ} \mathrm{C}, \mathrm{P}>25 \mathrm{kbar}$ and it remains stable in the diamond facies i.e., $>30 \mathrm{kbar}-800^{\circ} \mathrm{C}$ favoured $\mathrm{Fe} / \mathrm{Mg}$ in octahedral coordination side in case of staurolite. These assemblages aresupposed to grow during thegrowth of coreand inner mantleof garnet porphyry. Thepeakstageassemblages CoDol-Di, polycrystalline coesite associated with kyanite-eclogite yielded $\mathrm{T}-820^{\circ} \mathrm{C}$ and $34-39 \mathrm{kbar}$ has been restricted in the outer mantle and inner rim portion of garnet porphyry moderately within thelimit of diamond formation pressure. Nevethless there hasno record of diamond crystallization even though thesystem under diamond facies metamorphism.

The possible stabilization for diamond requires $C$ host mineral with cold subduction of geotherm about $\sim 7^{\circ} \mathrm{C} / \mathrm{Km}$ at depth $\sim 120 \mathrm{Km}$, i.e., deep subduction. Since such condition are essential transient during decompression of such long way back on surface, virtually no chance to survive through tectonic processes. One possibility for the survival of mantle pressure or diamond formation, recite enough stationary period, when the system in peak stage, asin the form of inclusion and armoring in the mechanically strong, pressure container like garnet and zircon. 